can be overcome using reconstituted Sendai virus envelopes and erythrocyte gliosts as membrane carriers of the oligonucleotide derivatives. Fast methods for incorporation of reactive oligonucleotide derivatives into membrane carriers have been developed. In the model experiments membrane carriers incorporating alkylating oligotlymidylate derivatives are delivered into ascite carcinona Krebs 2 cells and it is shown that llicy are transfered efficiently into cytosol and react wilh complementary poly (A) sequences of cellular RNAs. Efficiency of delivery of oligonucleotide reagents into colls $10-100$ times increases when using the membrane vehicles.

Y.IK 577.21

B. А. Вахитов, Ю. М. Никоноров

НУКЛЕОТИДНАЯ ПОСЛЕДОВАТЕЛЬНОСТЬ
БОЛЬНОГО ПОВТОРА 5 S ДНК
У ДИПТОИДНОЙ ПШЕНИЦЫ ТRITICUM MONOCOCCUM L.

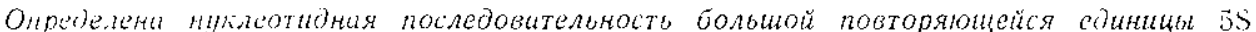

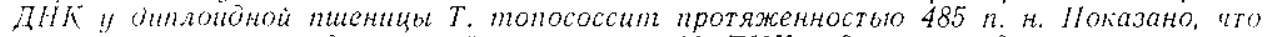

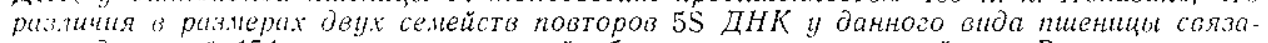
нot t deлещtей 154 h. н. в центральной области лежгенного спейсера. Выявлена оисо-

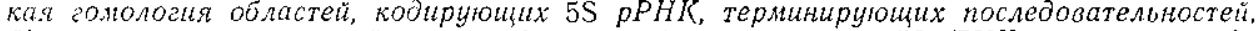

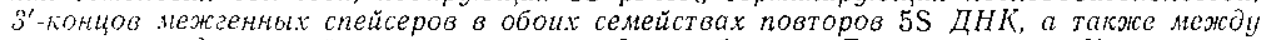

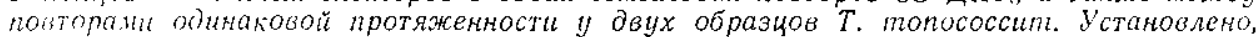

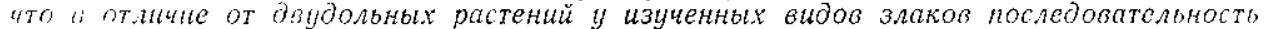

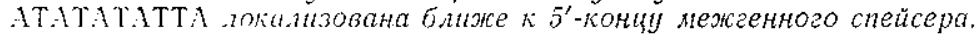

В геноме диплопдної пшеницы $T$. monococcum имелося гва семсйства повторяюпихся последовательностей ДНК, кодирующих $5 \mathrm{~S}$ рРІІК, раз. мерами около 320 и 500 п. н. [1]. Ранее они были клонированы пами в плазмидах $p T m 5 S 7$ и $p T m 5 S 12$ и тогда же определена пуклеотидная госледователынсть малого повтора $5 \mathrm{~S}$ ДНК [1]. В пастояней работе прсдставлена первичая структура $5 \mathrm{~S}$ ДНК размером 500 п. І., клонрованио̆ в плазмиле $p T m 5 S 12$.

Материалы и методы. В качестве объекта исследований использован ;цпплондый вид пшеницы $T$, monococcum (номер каталога ВИР - 8555). Методы выслления ДНК рекомбинантных плазмид, включения радиоактивной метки и определения первпчной структуры клонированиы фрагментов ДНК были подробно описаны нами в предыдущей работе [1].

Результаты и обсуждение. Для определения пернщиої структуры вставка рекомбинантной плазмиды $p T m 5 S 12$, содержащей $5 \mathrm{~S}$ ДНК $T$. monococcum размером около 500 п. г., была переклонирована в плазмиде $p U C 19$. Нуклеотидная последовательность гена $5 \mathrm{~S}$ рPНK п межгеніого спейсера представлена на рисунке. Для сравнения приведены также первичыс структуры $5 \mathrm{~S}$ ДНК в повторах размером 320 п. п. из этого же образца и 500 п. н., клонированной в плазмиде $p T m 5 S 73$ (T. monococcum, $\kappa-45297$ [2]).

Нуклеотидпую последовательность ДНК, кодируюпей $5 \mathrm{~S}$ plHK, ндентифицировали исходя из первичной структуры $5 \mathrm{~S}$ рPHK мягкой писпицы, определенной МакКеем іл др. [3]. Из рисунка вицно, что в направлении транскрипции клонированая нами $5 \mathrm{~S}$ ДНК содержит кодирующиї фрагмент размером 90 п. п., прсдставляющй собой $3^{\prime}$-конец одного гена, межгенный спейсер и фрагмент размером 30 п. п. $5^{\prime}$ конца гена $5 \mathrm{~S}$ рPНK следующего повтора. Следовательно, последоватсльность, узпаваемая рестриктазой $B a m H I$, находится впутри кодирующей области гега $5 \mathrm{~S}$ pPHK. 
-.7ниа повторяющейся единицы $5 \mathrm{~S}$ ДНК, клопрованой в плазмi1.le p Tm5S12, равна 485 п. I. Протяжснность послеловательоости, кодпріюдей $5 \mathrm{~S}$ р РНK, как и в плазмидах $p T m 5 S 7$ и pTm5S73, составляет 120 п. н. Ген $5 \mathrm{~S}$ рРНK пачинается с триплета GGA и заканчивается пуклетпдами ССС. Содержание GC-пар составляет 53,3\%. Сравнение пунтеондиы послсдовательпостей кодирующих областей $5 \mathrm{~S}$ ДНК в

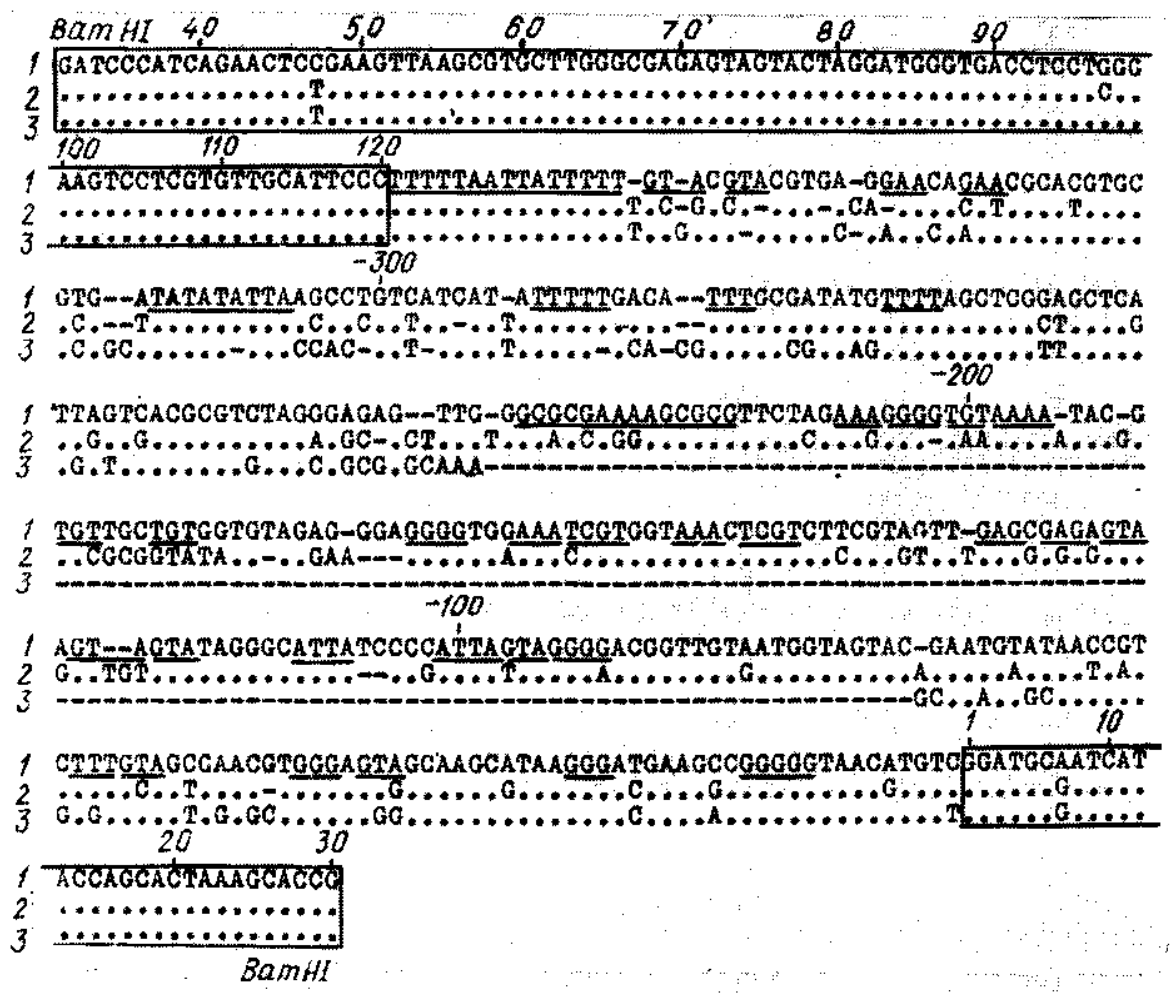

Hүклеспдые последовательности генов $5 \mathrm{~S}$ p PHK п межгениых спейсеров у диплондної у!шеницы $T$. monococcum, клонированыт в плазмидах pTm5S12 (I), pTm5S73 (2) it p7njs: (3). Кодирующая тасть закпючена в рамку. Сходные нуклсотиды обозиаченці точhами, а делецин - терточкой

Nuckotice sequences of $5 \mathrm{~S}$ rRNA genes and intergenic spacers of diploid wheat $T$. monocrecu". cloned in plasmids prm5S12 (1). pTm5S73 (2) and prm5S7 (3). Encoding part js : a frame. Similar nucleotides in sequences are indicated by dots and deletions by a das!i

повюрах о,ного семейства между двумя образцами $T$. monococcum (назмпды pTm5S12 и pTm5S73) показывает высокую гомологию меж:1у пми - 97,5\%. Нами выявлены всего три замены-G на A, C па T и $\mathrm{C}$ на G в положения 7,47 и 97 соответственіо.

Больное сходство нуклеотидных последователыностсй обнаруживается также между гепами $5 \mathrm{~S}$ рPHK, локализоваными в разиых семейстгах. Различия в их структуре связаны с заменами трех нуклсотидов 13 иаланиых на рисупке позициях. Замепы нуклеотидов в положениях 7 I 47 : генах $5 \mathrm{~S}$ pPHK, клонированных в плазмидах pTm5S7 и pTm5S73,

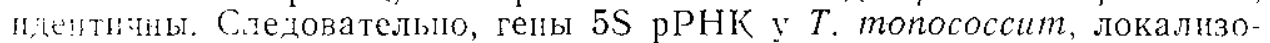
вапные в разлых семействах повторов $5 \mathrm{~S}$ ДНК, отличаются только заменами нуклетндов $C$ на $\mathrm{T}$ н $\mathrm{G}$ на $\mathrm{C}$ в положениях 57 и 97 соответctrentho.

Нзвестіо, что в геноме $T$. monococcum имсотся около 12000 колий генов 5S pPHK [4]. В данном случае мы сопоставили пуклеотидыые пюс.ледовательюсти только едининых гепов. Поэтому не исключено, тто 
среди множества копий могут быть и гены 5S pPHK с пдентишіої структурой независимо от их шринадлсжности к тому или нному ссмейству. Вероятіо, выявляемая гами псбольшая вариабелыность пуклеотндых последовательностей в генах $5 \mathrm{~S}$ рРНК является отражением внутригеномной микрогетерогенности их структуры в каждом семействс повторов. Ранее сходпое явление было выявлепо Герлахом и др. [5] при изучепин структуры генов $5 \mathrm{~S}$ рРНК, локализовапных в повторах размерами 410 и 500 н. н. у гексаплоидной шшеницы T. aestivum.

Протяженпость межгепного спейсера $5 \mathrm{~S}$ ДНК, клопировапной в плазмиде $p$ Tm5S12, составляет 365 п. I. Содержание GC-пар в дапно: области 5S ДНК значительно пиже, чсм в кодирующей части, и равио $45,2 \%$. Различия в размерах повторяющихся единиц $5 \mathrm{~S}$ ДНК, локализовапных в семействах длиной 320 и 500 п. н., связашы с делецисї 154 п. н. в центральой части межгенпого спсйсера. Виутривидовой 113менчивости длипы спейсера между генами $5 \mathrm{~S}$ pPHK в семействе повторов размером 500 п. гг. не выявляется.

B межгениом спейсерс непосредственио за геном $5 \mathrm{~S}$ pPHK лока.7нзована последовательность, терминируюлцая трапскрипцию. Она состоит из двух олиго-Т кластеров, образованиых из пяти пуклеотидов. В цсптральной области терминатора имеется небольшая палиндромпая последовательность ТААТТА. Сопоставляя эти области в составе плаз. мид $p T m 5 S 12$ и $p T m 5 S 73$, следует отметить в целом илептичность их структуры. В то же время у последней второй кластер состоит из шести Іуклеотидов. В ссмействе повторов $5 \mathrm{~S}$ ДНК длиной 320 п. I. терминатор также состонт нз 15 пуклеотидов и по структуре высокогомологичел ганной области большого повтора. Однако имеется одна особениости, В повторах плиной 500 п. пा. во втором кластере один нуклсотиц Т замснен на А. Қак известно, любые замены в дапной об.тасти остабIяют ес терминирующую способность (см. обзор [6]). Вероятіо, семейство повторов $5 \mathrm{~S}$ ДНК длиной 320 п. и. обладает более сплыым терминатором.

Характерной особенностью структуры мсжгенного спсйссра 5 S ДHК у данного вида пшеницы является паличие большого числа коротклх повторяющихся послс.двательностей (па рисупке подчеркнуты). В межгеншом спейсере ДНК, клонированной в плазмиде $\operatorname{Tin} 5 \mathrm{S12}$, пами обнӓружено около 30 сходых послсдовательностей. О,диако структра большинства из пих вариабельна. Наиболес копсервативпы последовательности $\mathrm{C}_{3-5}$ между пуклеотидами -10/-42, GTA $(-117 / \cdots-126)$, TCGT $(-141 /-150), \quad \mathrm{A}_{3-5}(-152 /-164,--196 /-200)$ и $\mathrm{T}_{3-5}(-270 /$ 1-293). В целом гомология пуклеотидных последователынстей мсжгенного спейсера в повторах длиной 500 п. п. между двумя образцами T. monococcum составляет $76 \%$, а межлу разными семействами в пределах одного гепома - 71,3\% (без учета целеции 154 п. н. в малом семействе повторов). В папной области повторов наря су с терминатором паиболсе конссрвативна последовательность, прилегающая к $5^{\prime}$-коншу гена $5 \mathrm{~S}$ рPНK (до - 35-го пуклеотида).

Обращаст па себя внимание тот факт, что как в кодирующей области, так и в $3^{\prime}$-конце межкеппого спейсера большииство различий в пуклеотидной последователыности связано с заменами пуклеотидов $\mathrm{C}$ па $\mathrm{T}$ и $\mathrm{G}$ па $\mathrm{A}$. Вероятно, это является следствием дезаминировапия метилированного цитозина и превращением его в тимин. Подробно этп аспекты рассматриваются в серии работ А. Л. Мазина и Б. Ф. Ванюшина $[7,8]$. Роль подобпых модификаций не совсем яспа, возможпо, опи имеют определенное отношение к фупкциольиом! состояІию генов.

Известп, что факторы, инициирующие и регулирующис трапскрнпцию генов $5 \mathrm{~S}$ рРНК, образовывают комплексы с последовательностями, локализовапными впутри кодирующей части между 45--97 пуклеотидами [9]. Однако роль нуклеотидиых последовательностей межгенного спейсера в обеспечении фупкционалыюй активности генов $5 \mathrm{~S}$ p PHK изучена педостаточно. Например, у Bombyx mori показано важное зпаче- 
ние последовательности ТАТАТАТТТТТТС, локализовапнй между -30/-16 пуклеотидами, для транскрипции гена $5 \mathrm{~S}$ pPHK в гетерологичной системе [10]. У Matthiola incana, Vigna radiata [11] и Lupinus luteus [12] сходная последовательность также локализовапа ближе к

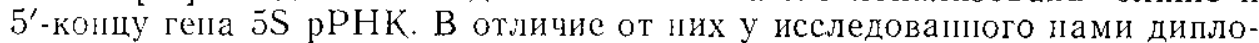
идного вида пнсницы $T$. monococcum, гексаплоидной пшеницы $T$. aest $i$ unm [5], Oryza sativa [13] и Secale cereale [14] эта послсдоватслыность пмсет иную локализацию. Она паходится между - 305/315 пуклеотидами в составе плазиид pTm5S12 и pTm5S73 и - 150/-159 нуклеотидами в $5 \mathrm{~S}$ ДНК длиной 320 п. п. При этом дапиые последоватсльности в повторах $5 \mathrm{~S}$ ДНК разных семеїств у $T$. monococcum пе идептичны. В позторах 5S ДНК с укороченшым межгелным спейсером она представлега посіс:ювателllостью ATATATTTA, а у большого повтора ATATATATTA. Возмонио, в геномах растений эти нуклеотидиые послсь⿻ватсльности выполияют такую же функцию, что и у $B$. mori. Следует поцчеркпуть специфическую локализацию данпой последовательІости у однодольных и двудольных растений. ГІо-видимому, это обстоятельство отражаст особсиности механизмов трапскринци генов $5 \mathrm{~S}$ pPIK ! растсниї, относящихся к разным классам.

Tакпм образом, на основе вышензложенного можло слслать вывод, что разиичия ғ размерах двух семейств повторов $5 \mathrm{~S}$ ДНК у циплоидпой пшенццы T. monococcum связаны с делецией 154 п. п. в цептралыной об.тасти медгенпго спейсера. Қодирующие $5 \mathrm{~S}$ рPНK области ДНК, тсрмпнирующе последоватсльности, $3^{\prime}$-конец межгеного спейссра, а также структра и локализация ряда простых повторяншихся последопательносей в нем высококонсервативны пезависимо от пх принадлежності к тому нти иному семейству повторов. Cходпая закономеріость обпаружела также в структуре повторяюшихся еннниц $5 \mathrm{~S}$ ДНК дииной 500 н. н. у двух образцов $T$. monococcum.

\section{СГИСОК ЛНТЕРАТУРЫ}

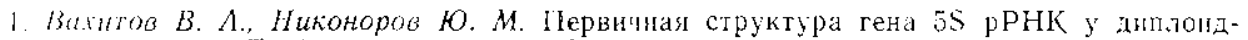
ної лисницы Triticum monococcum L. с укороченным нетранскрнбируемым спейссpoм // Молекуляр. биологня.- 1988.-22, \2 2.-. С. 406-413.

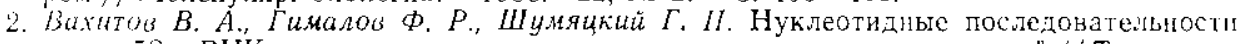
генов $5 \mathrm{~S}$ PPHK полнплокдных видов пшеницы и нх диких сородичей // Там жс.$1989-23$, V. 2. C. $431-440$.

3. Nucleotide sequences of wheat-embryo cytosol 5-s and 5,8-s ribosonal ribonucleic: acids/R. M. Mackey, D. F. Spercer, W. F. Doolittle, M. W. Gray//Eur. J. Biochem.-1980.-112, ^ 2. P. 56il-576.

4. Вахитоя В. А., Гиналов Ф. Р. Никоморов Ю. М. Определение чнсла копиї гелов, кодирующих $5 \mathrm{~S}$ pPHK и тPHK в геномах 43 видов пшениц и эгнлопсов// Генетиka.- 1986.-22, № 4.- C. $676-683$

5. Gerlach W. L., Dyer T. A. Sequence organization of the repeating units in tle nucleus of wheat which contain $5 S$ rRNA genes// Nuel. Acids Res. - 1980.-8, N 21.P. $4851-4865$.

6. Носиков B. В., Брога 9. А. Гены рибосомиых PHK // Итоги иауки и техники.М. : ВИНИТИ, 1982.- С. 110-215. (Сер. Биол. химня; Т. 18)

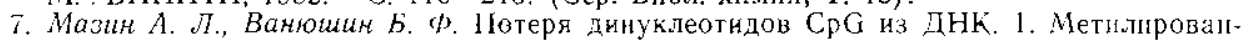
лый и неметилированмый компартменты генома у эукарнот с раз.личны содержанием 5-метнлцитозина в ДНК// Молекуляр. бнология.-1987,-21, № 2.- С. 万43$\overline{1} \overline{1}$.

8. Мазин А. Л., Ванюшин Б. Ф. Потеря динуклеотндов CpG нз ДНК. 2. Метилиовалиые и неметилированын гены позвоночных // Там же.- C. $552-562$.

9. Functional domains of the Xenopus laevis $5 \mathrm{~S}$ gene promoter/T. Pieler, S.-L.i Oci, J. Hamm et al. // EMBO J.-1985.-4, N 13B.- P. $3751-3756$

10. Morton $D . G$., Sprague $K$. $U$. In vitro transcription of silkworm $5 S$ RNA gene requieres an upstrearn signal//Proc. Nat. Acad. Sci. USA-1984.81, N 17.P. $5519-5522$

11. Hemleben $V$. Werts $D$. Sequence organization and putative regulatory elements in the 5S RNA genes of two ligher plants (Vigna radiata and Mathiola incana) // (icne. - 1988.-62, N 1.- P. 165-169.

12. Rafalski J. A. Wiewiorowski M., Söl D. Organization and nucleotide sequence of nuclear $5 \mathrm{~S}$ rRNA genes in yellow lupin (Lupinus luteus) // Nucl. Acids Res.- 1982.10. N 23.- P. 7635-7642.

13. Hariharan N., Reddy P. S., Radayatty J. D. $5 \mathrm{~S}$ rRNA genes in rice cmbryos// Plant Mol. Biol.- $1987 .-9, \therefore 5 .-$ P. 443-451. 
14. Lawrence G. J., Appels $R$. Mapping the nucleolus organizer region, seed pruiein inci and isozyme loci on chromosome $\mathrm{R}$ in rye//Theor. and Appl. Genet. N 5.-P. $742-749$.

Oтдеп бнохнмин

и пнтохимин Башкир. фил. АН СССР, Уфа

Полутен, $23.05,18$

NUCLEOTIDE SEQUENCE OF LARGE 5S DNA REPEAT

IN DIPLOID WHEAT TRITICUM MONOCOCCUM L.

V. A. Vakhitov, Yu. M. Nikonorov

Department of Biochemistry and Cytochemistry,

Bashkir I Branch of the Acadeny of Sciences of the USSR, Ufa

Sim mary

Nueleotide sequence of large $5 S$ DNA repeated unit 485 base pairs long, was levemined in diploid wheat Triticum monococcum. The differences in length in two fambles of $5 \mathrm{~S}$ DNS repeats in this wheat species are shown to be related to $154 \mathrm{~b}$. p. dcletion in central region of interencic spacer. A high homology of $5 \mathrm{~S}$ rRNA coding regions, tomatafing sequences, $3^{\prime}$-ends in intergenic spacers in both families of $5 \mathrm{~S}$ DNA repeats and aise in repeats of similar iongth in two samples of $T$. monococum is shown. Contrary to ticotyledon plants ATATATATTA sequence in cereal species under investigation is foind to be located nearer to $5^{\prime}$-end of the intergenic spacer.

УДК $577.217 ; 577.18 .02$

К. А. Содлаткин, О. В. Ковальчук, А. П. Потапов, А. В. Ельская.

Н. Ф. Крычецкая, Н. Г. Долшнная, З. А. ІІІабарова

\section{ДЕЗОКСИРИБОАНАЛОГ АНТИКОДОНОВОЙ ВЕТВИ ДРОЖЖЕВОЙ тРНК ${ }^{\text {Ph }}$ НЕ СПОСОБЕН К КОДОН-ЗАВИСИМОМУ СВЯЗЫВАНИЮ С МАЛЫМИ СУБЧАСТИЦАМИ РИБОСОМ ESCHERICHIA COLI И IIEЧЕНИ КРОЛИКА}

Для изуения в.ияния подификаций сахарофосфатного остова антикодоновоћ области

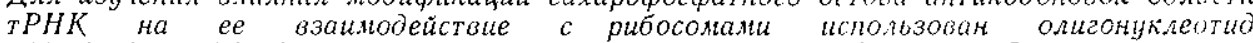
d (CCAGACTGAAGATCTGG), соответствиоший по никлеотнднй последовательност: немодифицировинмой антикодоновой ветви дрожжевой тPHК'ı. Показано, что данной олигонуклеотид в растворе образует внутринолекулярнио «ипильк», однако не спо-

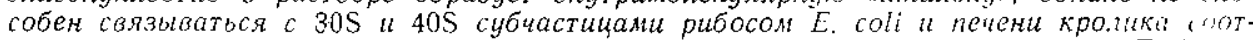
ветственно в присутствии рибо-(поли(U)) и дезоксирибо-(nоли(dT)) матрии. Добавление антибиотика неолицина В не меняло ситуации.

Введение. Д:я объяснения механизма отбора аминоацил-тРНК на рибосомах и транслокации предложена гипотеза стереоспецифической стабилизации кодон-антикодоновых комплексов, постулируюцая прямос взаимодействие декодирующего центра рибосом с сахарофосфатиым остовом кодон-антикодоновых дуплексов [1-4]. Согласно гипотезе, модификации сахарофосфатпого остова кодона пли аптикодона должны оказывать существеннос влияние па взаимодействие тРНК с программированной рибосомой. Природным вариантом полинуклеотида с «модифицированным» рибозофосфатным остовом является ДНК. В порме однотяжевая ДНК не может быть транслирована в беск.тсточнои белоксиптезирующей системе из $E$. coli, но в присутствии некоторых аминогликозидных антибиотиков, в первую очередь неомицина В, такая трансляция становится возможной [5-7].

В этой связи большой интерес представляет изучение влияпия модификаций сахарофосфатного остова аптикодоновой области тPHK пाа 